\title{
PKM PENGEMBANGAN SUMBER DAYA MANUSIA KELOMPOK SADAR WISATA KABUPATEN SITUBONDO
}

\section{PKM HUMAN RESOURCES DEVELOPMENT GROUP AWARENESS TOUR DISTRICT SITUBONDO}

\author{
Luckman Ashary ${ }^{1)}$ Rinta Santy Rukmana ${ }^{2)}$ Mahfud Siddiq ${ }^{3)}$ Lindiana ${ }^{4)}$, Ratih Puspita \\ Sari ${ }^{5)}$ Anita Pratama ${ }^{6}$ Putri Ayu Astiana ${ }^{7)}$ \\ ${ }^{1}$ Manajemen, Ekonomi, Universitas Abdurachman Saleh Situbondo \\ 2,3,4,5,6,7 Mahasiswa Program Studi Manajemen, Ekonomi, Univesritas Abdurachman Saleh \\ Situbondo \\ ${ }^{1}$ Email : luckman.ashary@gmail.com
}

\begin{abstract}
ABSTRAK
Pengabdian ini bertujuan untuk mengembangkan sumber daya manusia untuk masyarakat Situbondo dan memberdayakan potensi wisata yang kita miliki untuk meningkatkan pendapatan masyarakat. Sejauh ini potensi wisata yang dimiliki Kabupaten Situbondo sangat banyak tetapi belum maksimal dalam pengelolaannya. Penelitian ini adalah tentang pengembangan pariwisata daerah melalui studi kasus pengembangan sumber daya manusia di Kelompok Kesadaran Pariwisata di Kabupaten Situbondo, Provinsi Jawa Timur. Dalam Rencana Terpadu dan Program Investasi Infrastruktur Jangka Menengah Kabupaten Situbondo pada tahun 2016 - 2019 dinyatakan bahwa Perencanaan Pariwisata Kabupaten Situbondo di Kabupaten Situbondo diarahkan ke 4 Bidang Strategis, yaitu Bidang Strategis Ekonomi, Bidang Strategis Sosial Budaya, Strategi Strategis Teknologi Tinggi Area, dan Area Strategis Menyelamatkan Lingkungan. Peran sumber daya manusia memiliki peran penting dalam keberhasilan pengembangan dan pengembangan pariwisata daerah. Pendekatan yang digunakan dalam penelitian ini adalah deskriptif kualitatif, sumber data yang diperoleh berasal dari observasi lapangan, wawancara, diskusi kelompok dan dokumentasi. Pemerintah daerah telah mendorong pengembangan pariwisata daerah, terutama destinasi yang ada di sekitar masyarakat melalui pemberdayaan masyarakat sekitar untuk dapat mengelola destinasi mereka dengan baik. Dalam mengelola pariwisata, peran pemerintah daerah diperlukan dalam memberikan dorongan dan dukungan pendidikan di sektor pariwisata sehingga dapat mengisi kekosongan pekerja ahli untuk ditempatkan di lembaga / industri pariwisata. Pelaksanaan Kegiatan PKM dalam bentuk Pelatihan Manajemen Keuangan dan Manajemen Pemasaran dibagi menjadi 3 sesi, yaitu, penyebaran kuesioner / kuesioner, presentasi materi dan sesi terakhir adalah uji kasus. Hasil penelitian menunjukkan bahwa semua peserta mengalami peningkatan pengetahuan dan keseluruhan peningkatan pengetahuan peserta mencapai $85 \%$.
\end{abstract}

Kata kunci: Grup Kesadaran Pariwisata, Pengembangan SDM, Manajemen Keuangan, Manajemen Pemasaran. 


\title{
INTEGRITAS : Jurnal Pengabdian
}

Vol 3, No 2, Desember 2019

ISSN 2580-7978 (Cetak) ISSN 2615-0794 (Online)

\begin{abstract}
This study aims to develop human resources for the Situbondo community and empower the tourism potential that we have in order to increase people's income. So far the tourism potential owned by Situbondo Regency is very much but not yet maximized in its management. This research is about regional tourism development through human resource development case studies in Tourism Awareness Groups in Situbondo District, East Java Province. In the Integrated Plan and Medium Term Infrastructure Investment Program of Situbondo Regency in 2016 - 2019 it was stated that Situbondo District Tourism Planning in Situbondo Regency was directed to 4 Strategic Areas, namely Economic Strategic Areas, Socio-Cultural Strategic Areas, High-Tech Strategic Areas, and Strategic Areas Saving the Environment. The role of human resources has an important role in the success of development and development of regional tourism. The approach used in this study is descriptive qualitative, the source of data obtained comes from field observations, interviews, group discussions and documentation. Local governments have encouraged the development of regional tourism, especially destinations that are around the community through empowering surrounding communities to be able to manage their destinations well. In managing tourism the role of local government is needed in providing encouragement and supporting education in the tourism sector so that it can fill the vacancy of expert workers to be placed in the tourism institution / industry. The implementation of PKM Activities in the form of Financial Management Training and Marketing Management is divided into 3 sessions, namely, questionnaire / questionnaire distribution, material presentation and the last session is a test case. The results showed that all participants experienced an increase in knowledge and overall increased knowledge of participants reached $85 \%$.
\end{abstract}

Keywords: Tourism Awareness Group, HR Development, Financial Management, Marketing Management.

\section{PENDAHULUAN}

Penerapan otonomi daerah dalam kerangka penyelenggaraan pemerintah daerah memberikan kesempatan bagi pemerintah dilevel daerah untuk mengurus, mengelola, dan mengatur sebagian besar kebutuhan dan kepentingan masyarakatnya lebih leluasa. Hal tersebut secara tegas dijelaskan dalam UndangUndang Nomor 23 Tahun 2014 tentang Pemerintahan Daerah yang memberikan penjelasan tentang daerah otonom dimana kabupaten/kota mempunyai hak, wewenang dan berkewajiban mengatur dan mengurus rumah tangganya sendiri 


\section{INTEGRITAS : Jurnal Pengabdian}

dimana diberikan sumber - sumber keuangan untuk dapat membiayai penyelenggaraan pemerintahan dan pembangunan di daerahnya masing - masing. Hal ini ditujukan supaya masing - masing daerah memiliki kesempatan dalam meningkatkan pendapatan asli daerahnya.

Secara prinsip, otonomi daerah pada tingkat pemerintahan kabupaten dan kota dalam rangka pembangunan dikhususkan kepada pembangunan berbasis tingkatan terendah dalam sistem pemerintahan di Indonesia yaitu desa. Peraturan tentang otonomi daerah pada tingkat pemerintahan desa terdapat di dalam Undang-Undang Nomor 6 Tahun 2014 tentang Desa, dimana desa dalam penyelenggaraan sistem pemerintahan terendah mempunyai hak dan kewajiban untuk mengatur dan mengurus urusan pemerintahan, kepentingan masyarakat setempat berdasarkan prakarsa masyarakat, hak asal usul, dan/atau hak tradisional yang diakui dan dihormati dalam sistem pemerintahan Negara Kesatuan Republik Indonesia (NKRI).

Berdasarkan perubahan kondisi tersebut, maka dalam konteks pendanaan Desa harus mampu menyusun program kerja dan mempertanggungjawabkan Anggaran Pendapatan dan Belanja pemerintah desa (APBDesa) yang secara garis besar terdiri dari belanja dan pendapatan desa.

Dalam hal pengelolaan Pendapatan, desa berhak mengelola dan menggali potensi - potensi yang terdapat didesanya sehingga dapat meningkatkan Pendapatan Asli Desa (PADes). Salah satu potensi yang dapat ditingkatkan menjadi Pendapatan Asli Desa (PADes) di Indonesia adalah sektor pariwisata. Pengembangan sektor pariwisata sebagai salah satu bagian dari pengembangan sektor ekonomi kreatif saat ini menjadi salah satu program prioritas pembangunan pemerintah pusat.

Program pembangunan lima tahun ke depan yang terfokus pada infrastruktur, maritim, energi, pangan, dan pariwisata menempatkan pariwisata sebagai leading sector. Gerakan Sadar Wisata dan Aksi Sapta Pesona Wisata merupakan satu diantara sepuluh program prioritas Kementrian Pariwisata (Kempar) sebagai 


\section{INTEGRITAS : Jurnal Pengabdian}

upaya meningkatkan daya saing pariwisata Indonesia di ranah persaingan global. Di samping dapat mendatangkan devisa bagi negara, pengembangan sektor pariwisata di beberapa daerah terbukti mampu memberikan dampak perubahan yang luas.

Pembangunan kepariwisataan, sebagaimana halnya pembangunan di sektor lainnya, pada hakekatnya melibatkan peran dari seluruh pemangku kepentingan yang ada dan terkait. Pemangku kepentingan yang dimaksud meliputi 3 (tiga) pihak yaitu: Pemerintah, Swasta dan Masyarakat, dengan segenap peran dan fungsinya masing - masing. Masing-masing pemangku kepentingan tersebut tidak dapat berdiri sendiri, namun harus saling bersinergi dan melangkah bersama-sama untuk mencapai dan mewujudkan tujuan dan sasaran pembangunan yang disepakati. Gambar 1. dibawah ini menunjukkan keterkaitan dan sinergi antar pemangku kepentingan dalam kegiatan pembangunan kepariwisataan.

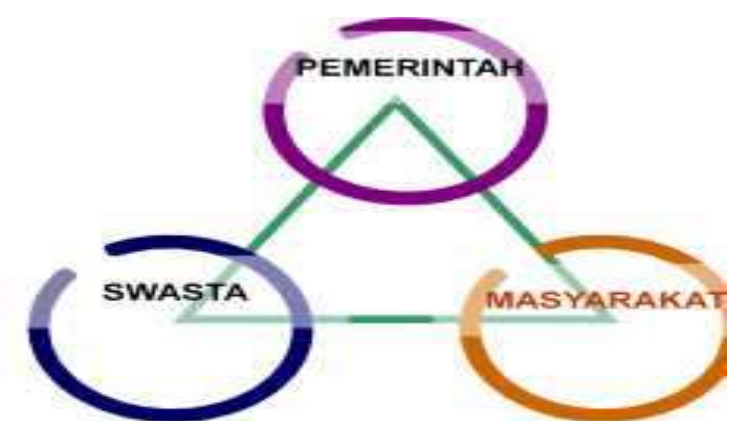

Gambar 1. Pemangku Kepentingan dalam Pembangunan Pariwisata Sumber: Murphy, 1990

Penjelasan peran dan fungsi masing-masing pemangku kepentingan tersebut secara rinci adalah sebagai berikut:

1. Pemerintah sesuai dengan tugas dan kewenangannya menjalankan peran dan fungsinya sebagai fasilitator dan pembuat peraturan (regulator) dalam kegiatan pembangunan kepariwisataan. 


\section{INTEGRITAS : Jurnal Pengabdian}

2. Kalangan Swasta (pelaku usaha/ industri pariwisata) dengan sumber daya, modal dan jejaring yang dimilikinya menjalankan peran dan fungsinya sebagai pengembang dan atau pelaksana pembangunan kegiatan kepariwisataan;

3. Masyarakat dengan sumber daya yang dimiliki, baik berupa adat, tradisi dan budaya serta kapasitasnya, berperan sebagai tuan rumah (host), namun juga sekaligus memiliki kesempatan sebagai pelaku pengembangan kepariwisataan sesuai kemampuan yang dimilikinya.

Peningkatan peran masyarakat dalam pembangunan kepariwisataan memerlukan berbagai upaya pemberdayaan (empowerment), agar masyarakat dapat berperan lebih aktif dan optimal serta sekaligus menerima manfaat positif dari kegiatan pembangunan yang dilaksanakan untuk peningkatan kesejahteraannya. Pemberdayaan Masyarakat dalam konteks pembangunan kepariwisataan dapat didefinisikan sebagai:

"Upaya penguatan dan peningkatan kapasitas, peran dan inisiatif masyarakat sebagai salah satu pemangku kepentingan, untuk dapat berpartisipasi dan berperan aktif sebagai subjek atau pelaku maupun sebagai penerima manfaat dalam pengembangan kepariwisataan secara berkelanjutan”. (Renstra Dit. Pemberdayaan Masyarakat, 2010)

Definisi tersebut menegaskan posisi penting masyarakat dalam kegiatan pembangunan, yaitu masyarakat sebagai subjek atau pelaku pembangunan dan masyarakat sebagai penerima manfaat pembangunan. Masyarakat sebagai subyek atau pelaku pembangunan, mengandung arti, bahwa masyarakat menjadi pelaku penting yang harus terlibat secara aktif dalam proses perencanaan dan pengembangan kepariwisataan, bersama-sama dengan pemangku kepentingan terkait lainnya baik dari pemerintah maupun swasta. Sadar Wisata dalam hal ini digambarkan sebagai bentuk kesadaran masyarakat untuk berperan aktif dalam 2 (dua) hal berikut, yaitu: 


\section{INTEGRITAS : Jurnal Pengabdian}

1. Masyarakat menyadari peran dan tanggung jawabnya sebagai tuan rumah (host) yang baik bagi tamu atau wisatawan yang berkunjung untuk mewujudkan lingkungan dan suasana yang kondusif sebagaimana tertuang dalam slogan Sapta Pesona.

2. Masyarakat menyadari hak dan kebutuhannya untuk menjadi pelaku wisata atau wisatawan untuk melakukan perjalanan ke suatu daerah tujuan wisata, sebagai wujud kebutuhan dasar untuk berekreasi maupun khususnya dalam mengenal dan mencintai tanah air.

Sapta Pesona, sebagaimana disinggung di atas adalah :

“7 (tujuh) unsur pesona yang harus diwujudkan bagi terciptanya lingkungan yang kondusif dan ideal bagi berkembangnya kegiatan kepariwisataan di suatu tempat yang mendorong tumbuhnya minat wisatawan untuk berkunjung”.

Ketujuh unsur Sapta Pesona yang dimaksud di atas adalah :

1. Aman

2. Tertib

3. Bersih

4. Sejuk

5. Indah

6. Ramah

7. Kenangan

Terwujudnya ketujuh unsur Sapta Pesona dalam pengembangan kepariwisataan di daerah akan bermuara pada:

a. Meningkatnya minat kunjungan wisatawan ke destinasi

b. Tumbuhnya iklim usaha kepariwisataan yang prospektif

c. Meningkatnya lapangan pekerjaan dan peluang pendapatan, serta dampak ekonomi multi ganda pariwisata bagi masyarakat.

Sadar Wisata dan Sapta Pesona sebagai unsur penting dalam mendukung pengembangan destinasi pariwisata tentu tidak dapat terwujud secara otomatis tanpa adanya langkah dan upaya-upaya untuk merintis, menumbuhkan, 


\section{INTEGRITAS : Jurnal Pengabdian}

mengembangkan dan melaksanakan secara konsisten di destinasi pariwisata. Oleh karena itu, perlu ditumbuhkan peran serta masyarakat secara aktif dalam mengembangkan Sadar Wisata dan Sapta Pesona bersama-sama dengan pemangku kepentingan terkait lainnya. Dalam hal ini Kelompok Sadar Wisata (Pokdarwis) atau kelompok penggerak pariwisata sebagai bentuk kelembagaan informal yang dibentuk anggota masyarakat (khususnya yang memiliki kepedulian dalam mengembangkan kepariwisataan di daerahnya).

Gambaran posisi dan peran penting Kelompok Sadar Wisata (Pokdarwis) dikaitkan dengan pengembangan kepariwisataan / destinasi pariwisata tersebut dapat diilustrasikan pada Gambar 2 di bawah ini:

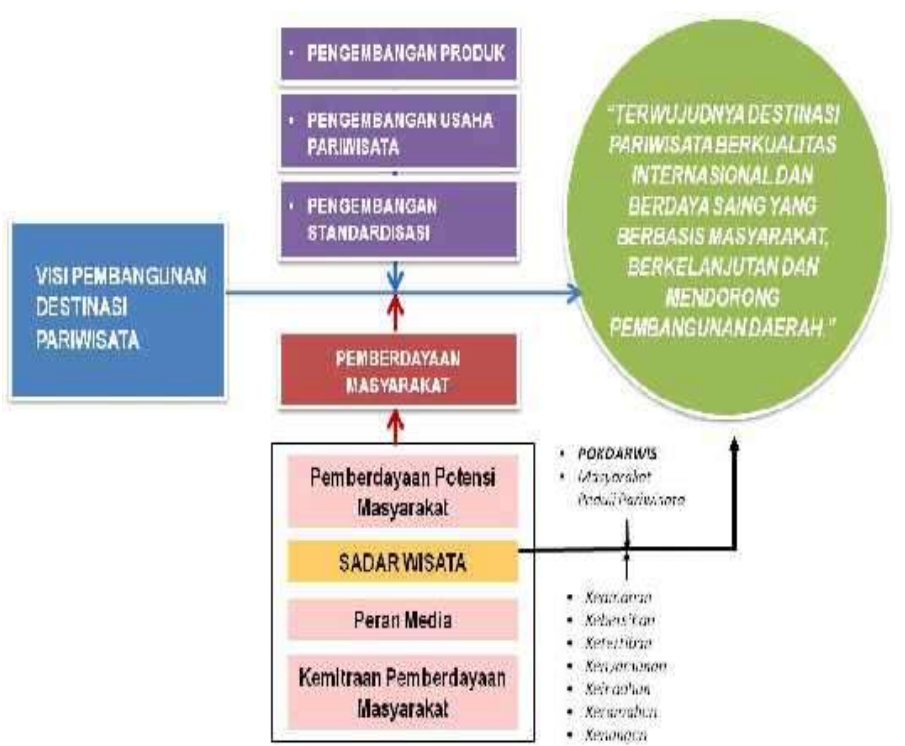

Gambar 2. Peran dan Posisi Penting Kelompok Sadar Wisata (Pokdarwis)

Keberadaan Pokdarwis dalam konteks pengembangan destinasi pariwisata telah berperan sebagai salah satu "unsur penggerak" dalam turut mendukung terciptanya lingkungan dan suasana yang kondusif di tingkat lokal di daerahnya, yang secara kolektif akan berdampak positif bagi perkembangan destinasi pariwisata dalam konteks wilayah yang lebih luas. Peran dan kontribusi Pokdarwis tersebut perlu terus didukung dan dikembangkan baik secara kualitas 


\section{INTEGRITAS : Jurnal Pengabdian}

maupun kuantitas dalam turut menopang perkembangan dan pertumbuhan destinasi pariwisata, maupun khususnya peningkatan peran masyarakat dalam pembangunan kepariwisataan di daerahnya masing-masing. Oleh karena itu Pedoman Pengembangan Pokdarwis diperlukan sebagai panduan bagi Pemerintah di tingkat Pusat maupun Daerah dalam melakukan pembinaan terhadap Pokdarwis.

\section{TARGET DAN LUARAN}

Kabupaten Situbondo merupakan sebuah kabupaten di Provinsi Jawa Timur, Indonesia dengan pusat pemerintahan dan ibu kota kabupaten terletak di Kecamatan Situbondo. Kabupaten ini terletak di daerah pesisir utara pulau Jawa, di kawasan Tapal Kuda dan dikelilingi oleh perkebunan tebu, tembakau, hutan lindung Baluran dan lokasi usaha perikanan. Letaknya strategis, berada di tengah jalur transportasi darat Jawa - Bali, kegiatan perekonomiannya tampak aktif. Situbondo mempunyai pelabuhan Panarukan yang terkenal sebagai ujung timur dari Jalan Raya Pos Anyer - Panarukan di pulau Jawa yang dibangun oleh Daendels pada era kolonial Belanda.

Seperti kita ketahui bahwa menciptakan sebuah industri pariwisata tidaklah semudah membalikkan telapak tangan dibandingkan dengan pekerjaan di industri lain seperti tambang ataupun sektor perkebunan. Kabupaten Situbondo sebagai salah satu Kabupaten yang memiliki beragam destinasi wisata bahari dan wisata desa sangatlah disayangkan jika dalam pengelolaan pembangunan di bidang kepariwisataan mengalami perkembangan yang kurang signifikan. Hal ini disebabkan oleh :

1. Kurangnya keterlibatan komponen masyarakat baik secara Institusional maupun Akademisi dalam Pembinaan Kelompok Sadar Wisata (Pokdarwis) di Kabupaten Situbondo.

2. Kurangnya wawasan dan kesadaran masyarakat lokal akan pentingnya pembangunan di bidang kepariwisataan. 


\section{INTEGRITAS : Jurnal Pengabdian}

Vol 3, No 2, Desember 2019

3. Kurang aktifnya peran serta Kelompok Sadar Wisata (Pokdarwis) yang ada di Kabupaten Situbondo. Hal ini dikarenakan sumber daya manusia yang tergabung dalam Pokdarwis memiliki tingkat pengetahuan dan kualitas yang masih rendah dibidang manajemen.

4. Kurangnya sinergitas antara Kelompok Sadar Wisata (Pokdarwis) dengan instansi terkait sehingga terkesan diabaikan dan kurang terkoordinasi dengan baik. 


\section{INTEGRITAS : Jurnal Pengabdian}

Vol 3, No 2, Desember 2019

ISSN 2580-7978 (Cetak) ISSN 2615-0794 (Online)

Identifikasi permasalahan masyarakat seperti tampak pada Gambar 3.

berikut:

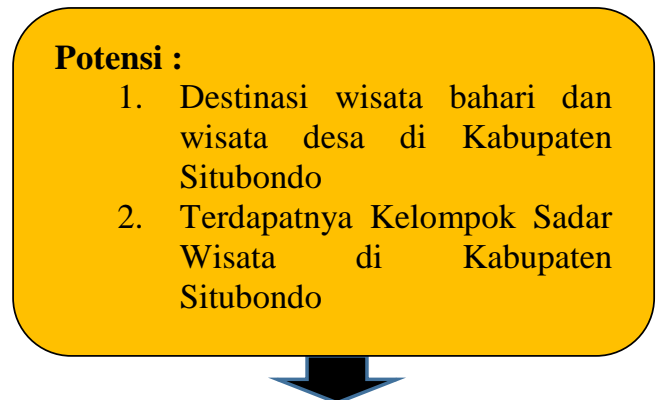

\section{Permasalahan :}

1. Kurangnya keterlibatan komponen masyarakat baik secara Institusional maupun Akademisi dalam Pembinaan Kepariwisataan di Kabupaten Situbondo.

2. Kurangnya wawasan dan kesadaran masyarakat lokal akan pentingnya pembangunan di bidang kepariwisataan.

3. Kurang aktifnya peran serta Kelompok Sadar Wisata (Pokdarwis) yang ada di Kabupaten Situbondo. Hal ini dikarenakan sumber daya manusia yang tergabung dalam Pokdarwis memiliki tingkat pengetahuan dan kualitas yang masih rendah dibidang manajemen.

4. Kurangnya sinergitas antara Kelompok Sadar Wisata (Pokdarwis) dengan instansi terkait sehingga terkesan diabaikan dan kurang terkoordinasi dengan baik.

\section{Alternatif Pemecahan masalah :}

1. Pengembangan Sumber Daya Manusia (SDM) Kelompok Sadar Wisata (Pokdarwis) bisa dilakukan melalui pendidikan, pelatihan managerial dan keikutsertaan dalam seminar, diskusi, dan lain sebagainya di bidang-bidang kepariwisataan.

2. Kemitraan atau kerja sama dapat saling menguntungkan antara pihak pengelola desa wisata dengan para pengusaha pariwisata di kota atau pihak pembina desa wisata dalam hal ini pihak dinas pariwisata daerah. Bidang-bidang usaha yang dikerjakasamakan antara lain seperti bidang akomodasi, perjalanan, promosi, pelatihan, dan lain-lain.

3. Membina organisasi masyarakat. Penduduk desa yang biasanya merantau kemudian mudik atau tradisi lain dapat dibina dan diorganisir untuk memajukan desa wisata mereka.

4. Kerja sama dengan universitas. Kerja sama sebaiknya dilakukan dengan universitas atau perguruan tinggi yang melakukan pengembangan dan pengabdian supaya dilaksanakan di desa wisata. Hal ini guna membuka peluang dan masukan bagi kegiatan di desa wisata.

Berkembangnya SDM Kelompok Sadar Wisata (Pokdarwis) di Kabupaten Situbondo

Gambar 3. Kerangka Pemecahan Masalah 


\section{Khalayak Sasaran Antara Yang Strategis}

Khalayak sasaran yang strategis dalam kegiatan ini adalah anggota Kelompok Sadar Wisata (Pokdarwis) di Kabupaten Situbondo. Jumlah peserta pelatihan sebanyak 20 orang. Mitra berperan sebagai subjek yang akan melakukan seluruh kegiatan pemberdayaan dalam melakukan Penyuluhan, Pembinaan dan Pelatihan bagi anggota Kelompok Sadar Wisata (Pokdarwis) di Kabupaten Situbondo.

\section{Keterkaitan}

Kegiatan Pengabdian Masyarkat ini tidak akan berhasil tanpa adanya keterkaitan dengan beberapa pihak lain. Dalam hal ini pihak Dinas Pariwisata Kabupaten Situbondo, Perangkat Desa serta anggota Kelompok Sadar Wisata (Pokdarwis) di Kabupaten Situbondo.

\section{METODE PELAKSANAAN}

Sasaran pelatihan ditujukan kepada anggota Kelompok Sadar Wisata (Pokdarwis) di Kabupaten Situbondo. Setelah dilakukan pendidikan, penyuluhan dan pelatihan maka anggota Pokdarwis dituntuk untuk dapat menerapkan hasil pelatihan dalam mengembangkan wisata bahari dan wisata desa. Metode pelaksanaan kegiatan pengabdian kepada masyarakat melalui pengembangan anggota Kelompok Sadar Wisata (Pokdarwis) di Kabupaten Situbondo. Tahapan - tahapan pelaksanaan pelatihan pengembangan anggota Kelompok Sadar Wisata (Pokdarwis) di Kabupaten Situbondo adalah sebagai berikut:

a. Tahap persiapan

Persiapan yang dilakukan meliputi : survey lapangan, observasi dan sosialisasi.

b. Tahap pelaksanaan kegiatan yang berupa pelatihan dilakukan kepada anggota Kelompok Sadar Wisata (Pokdarwis) di Kabupaten Situbondo yang meliputi pelatihan tentang manajemen keuangan dan manajemen pemasaran, pelatihan tentang penggunaan teknologi informasi terutama sosial media guna mempromosikan wisata bahari ataupun wisata desa di Kabupaten Situbondo. Setelah pelatihan dilaksanakan, mitra akan melakukan latihan atau praktek langsung untuk menerapkan ilmu yang diperoleh dari pelatihan. 


\section{INTEGRITAS : Jurnal Pengabdian}

\section{c. Tahap Evaluasi}

Tahap evaluasi pelatihan ini dilakukan melalui pengamatan langsung mengenai kinerja anggota Kelompok Sadar Wisata (Pokdarwis) di Kabupaten Situbondo. Evaluasi ini dilakukan oleh instruktur dengan mengacu pada indikator yang tercantum dalam lembar penilaian. Melalui evaluasi ini, mitra dapat membahas permasalahan yang muncul dan mencari solusi yang kreatif dalam rangka keberlanjutan program. Contoh lembar penilaian adalah seperti berikut:

Tabel 1. Lembar Penilaian

\begin{tabular}{|c|c|c|c|c|c|}
\hline \multirow{2}{*}{ No } & \multirow{2}{*}{ Indikator Penilaian } & \multicolumn{4}{|c|}{ Skala Nilai* $^{*}$} \\
\hline & & 4 & 3 & 2 & 1 \\
\hline 1. & $\begin{array}{l}\text { Pemahaman tentang managerial } \\
\text { kepariwisataan }\end{array}$ & & & & \\
\hline 2. & $\begin{array}{l}\text { Pemahaman tentang struktur } \\
\text { organisasi Pokdarwis beserta } \\
\text { Job Discriptionnya }\end{array}$ & & & & \\
\hline 3. & $\begin{array}{l}\text { Pemahaman tentang } \\
\text { penggunaan sosial media }\end{array}$ & & & & \\
\hline 4. & $\begin{array}{lr}\text { Pemahaman } & \text { tentang } \\
\text { peningkatan } & \text { kreativitas } \\
\text { masyarakat } & \end{array}$ & & & & \\
\hline 5. & $\begin{array}{l}\text { Pemahaman tentang Sadar } \\
\text { Wisata dan Sapta Pesona }\end{array}$ & & & & \\
\hline
\end{tabular}

*) 4 = sangat baik, $3=$ baik, $2=$ cukup, $1=$ kurang

Tabel 2. Klasifikasi Nilai

\begin{tabular}{|l|l|l|l|}
\hline No & Rentang Nilai & Nilai & Kategori \\
\hline 1. & $85-100$ & 4 & Sangat baik \\
\hline 2. & $70-84$ & 3 & Baik \\
\hline 3. & $55-69$ & 2 & Cukup \\
\hline 4. & $<54$ & 1 & Kurang \\
\hline
\end{tabular}

\section{Metode Pendekatan yang Ditawarkan pada Mitra}

Kegiatan pengembangan anggota Kelompok Sadar Wisata (Pokdarwis) di Kabupaten Situbondo dengan menggunakan metode PRA (Participatory Rural Appraisal). Metode ini dipilih karena keterlibatan masyarakat dalam hal ini adalah anggota Kelompok Sadar Wisata (Pokdarwis) di Kabupaten Situbondo sangat diperlukan dalam seluruh kegiatan. PRA adalah suatu pendekatan yang memungkinkan masyarakat desa untuk saling 


\section{INTEGRITAS : Jurnal Pengabdian}

berbagi, meningkatkan dan menganalisis pengetahuan mereka tentang kondisi dan kehidupan desa, membuat rencana dan bertindak (Chamber, 1996). Tujuan utama metode PRA adalah menghasilkan rancangan program yang lebih sesuai dengan hasrat dan keadaan masyarakat dan lebih lanjut, PRA juga bertujuan memberdayakan masyarakat, yakni dengan kemampuan masyarakat dalam mengkaji keadaan mereka sendiri, kemudian melakukan perencanaan dan tindakan.

\section{Evaluasi Pelaksanaan Program}

Tahap evaluasi pelaksanan program dibagi menjadi 2 tahap. Evaluasi tahap pertama dilakukan oleh mitra mengenai pengamatan dari implementasi hasil pelatihan. Evaluasi tahap kedua dilakukan dalam rangka menilai kinerja dari anggota Kelompok Sadar Wisata (Pokdarwis) di Kabupaten Situbondo melalui Lembar Penilaian.

\section{HASIL DAN PEMBAHASAN}

Sesuai kesepakatan antara Tim dengan Kelompok Sadar Wisata dalam mendiskusikan kegiatan pengabdian kepada masyarakat ini, bahwa kegiatan dilakukan sesuai kebutuhan masyarakat dan sesuai dengan apa yang telah direncanakan dan disepakati bersama. Pelaksanaan pelatihan guna meningkatkan SDM (Sumber Daya Manusia) agar mengetahui Manajemen Keuangan dan Manajemen Pemasaran. Tabel 3. Rencana Kegiatan yang Disepakati

\begin{tabular}{|c|l|c|c|c|c|c|c|c|c|}
\hline No. & \multicolumn{2}{|c|}{ Nama Kegiatan } & \multicolumn{3}{c|}{ April } & \multicolumn{3}{c|}{ Mei } \\
\cline { 3 - 10 } & & 1 & 2 & 3 & 4 & 1 & 2 & 3 & 4 \\
\hline 1. & $\begin{array}{l}\text { Perencanaan dan rapat bersama wakil } \\
\text { kelompok sadar wisata. }\end{array}$ & & & & & & & & \\
\hline 2. & Perlengkapan materi dan fasilitas & & & & & & & & \\
\hline 3. & Persiapan pelatihan & & & & & & & & \\
\hline 4. & Pemantapan pelatihan & & & & & & & & \\
\hline 5. & Pelaksanaan pelatihan & & & & & & & & \\
\hline 6. & Evaluasi & & & & & & & & \\
\hline
\end{tabular}




\section{INTEGRITAS : Jurnal Pengabdian}

Tabel 4. Hasil Evaluasi Peningkatan Pengetahuan Peserta Pelatihan

\begin{tabular}{|c|c|c|c|c|c|}
\hline \multirow[t]{2}{*}{ No } & \multirow{2}{*}{$\begin{array}{l}\text { Kelompok } \\
\text { Desa }\end{array}$} & \multirow{2}{*}{$\begin{array}{l}\text { Juml } \\
\text { ah } \\
\text { Peser } \\
\text { ta }\end{array}$} & \multicolumn{2}{|c|}{ Rerata Nilai Peserta } & \multirow{2}{*}{$\begin{array}{l}\text { Peningkatan } \\
(\%)\end{array}$} \\
\hline & & & $\begin{array}{l}\text { Sebelum } \\
\text { Kegiatan } \\
\text { Pelatihan }\end{array}$ & $\begin{array}{l}\text { Sesudah } \\
\text { Kegiatan } \\
\text { Pelatihan }\end{array}$ & \\
\hline 1 & $\begin{array}{l}\text { Pokdarwis } \\
\text { Tampora }\end{array}$ & 1 & 10 & 72 & $620 \%$ \\
\hline 2 & Kendit & 1 & 25 & 48,5 & $94 \%$ \\
\hline 3 & Suboh & 1 & 45 & 54 & $20 \%$ \\
\hline 4 & Olean & 2 & 60 & 103 & $72 \%$ \\
\hline 5 & JBS & 2 & 20 & 127 & $535 \%$ \\
\hline 6 & Kp. Blekok & 3 & 135 & 143,5 & $6 \%$ \\
\hline & Keseluruhan & 10 & 49,16 & 91,33 & $85 \%$ \\
\hline
\end{tabular}

*) selisih sesudah kegiatan - sebelum kegiatan dibagi sebelum kegiatan dikali $100 \%$

Berdasarkan tabel di atas dapat diketahui bahwa Pokdarwis Tampora mendapatkan nilai 10 untuk pengisian kuesioner. Nilai itu bertambah menjadi 72 setelah mereka mendapatkan pelatihan Pengembangan Sumber Daya Manusia, Manajemen Keuangan dan Manajemen Pemasaran dengan presentase kenaikan mencapai 620\%. Hal ini menunjukkan bahwa Pokdarwis Tampora sudah memahami mengenai Pengembangan MSDM, Manajemen Keuangan dan Manajemen Pemasaran.

Begitupun dengan pokdarwis Kendit, nilai awal mereka 25 menjadi 48,5, dengan kenaikan 94\%. Selanjutnya dengan pokdarwis Suboh, nilai awal mereka 45 naik menjadi 59 fengan peningkatan presentase sebesar 20\%. Berikutnya Desa Olean dengan nilai 60 meningkat menjadi 103, presentase yang diperoleh sebesar 72\%. Yang hadir pada acara ini ialah Desa JBS denga perolehan nilai sebelum kegiatan sebesar 20 dan meningkat menjadi 127 dengan presentase 535\%, berikutnya kampung Blekok dengan perolehan nilai 135 meningkat menjadi 143,5, sehingga hal ini menjukkan bahwa mereka mengalami peningkatan pengetahuan dari sebelum pelaksanaan sehingga selesai pelaksanaan.

Bila dilihat secara keseluruhan dalam tabel 4, dari test case yang telah kita berikan kepada peserta pelatihan, menunjukkan bahwa setiap perwakilan dari masing-masing Pokdarwis di Kabupaten Situbondo yang mengikuti Pelatihan 


\section{INTEGRITAS : Jurnal Pengabdian}

Vol 3, No 2, Desember 2019

Manajemen Keuangan dan Manajemen Pemasaran mengalami peningkatan pengetahuan dan nilai secara keseluruhan peningkatan pengetahuan peserta pelatihan mencapai $85 \%$. Hal ini menunjukkan bahwa terdapat perbedaan nyata antara sebelum di laksanakan pelatihan dan setelah kegiatan dilaksanakan.

Jumlah keseluruhan pokdarwis yang berada di wilayah Kabupaten Situbondo sebanyak 21 dan telah menerima undangan dari kami untuk menghadiri acara pelatihan. Namun yang hadir pada acara tersebut hanya ada 10 pokdarwis yaitu, Pokdarwis Tampora, Pokdarwis JMK, Pokdarwis Kalianget, Wisata JBS, Pokdarwis Kp. Blekok, Pokdarwis Agol, Pokdarwis Mimbaan, Pokdarwis Ollean, Pokdarwis Suboh dan Pokdarwis Kendit.

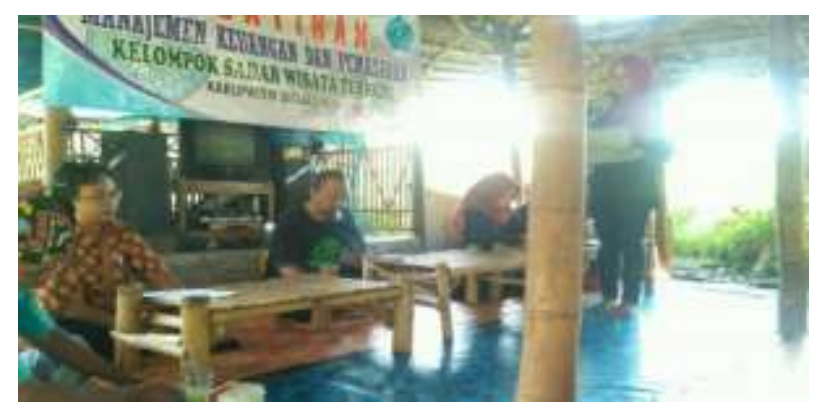

Gambar 4. Pembukaan Oleh Moderator

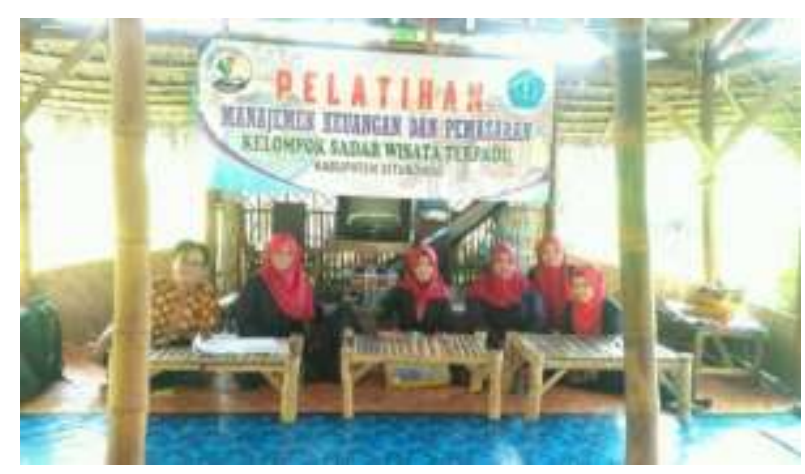

Gambar 5. Tim Pengabdian Masyarakat 


\section{INTEGRITAS : Jurnal Pengabdian}

Vol 3, No 2, Desember 2019

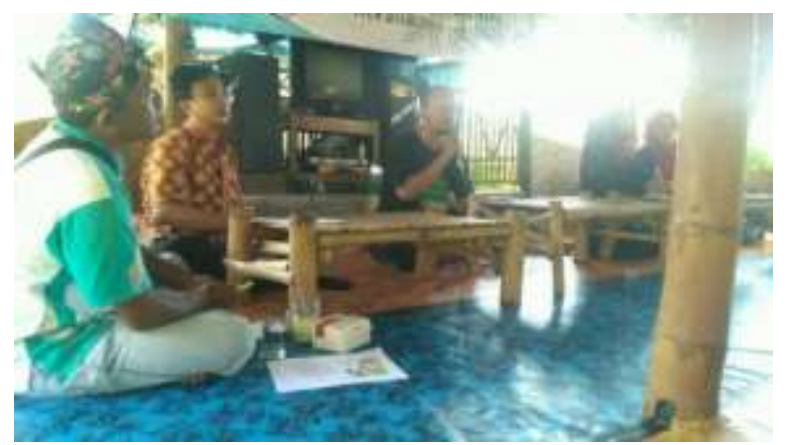

Gambar 6. Sambutan oleh ketua Pokdarwis Terpadu Bapak Agung Harianto

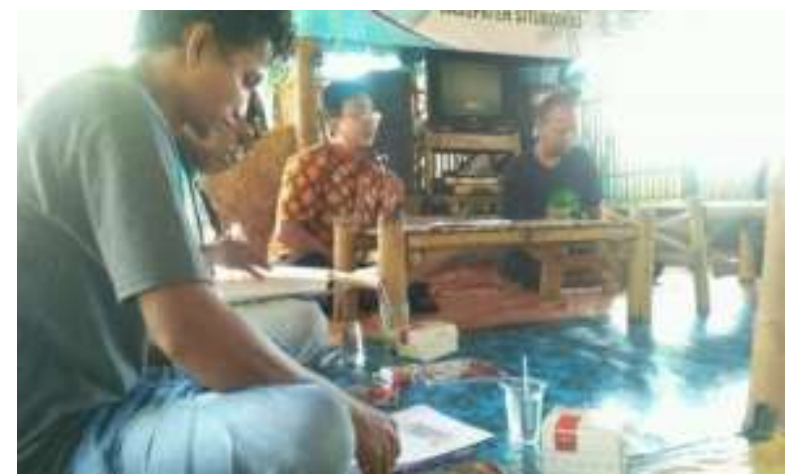

Gambar 7. Penyampaian Materi Pengembangan SDM oleh Luckman Ashary S.E., M.M

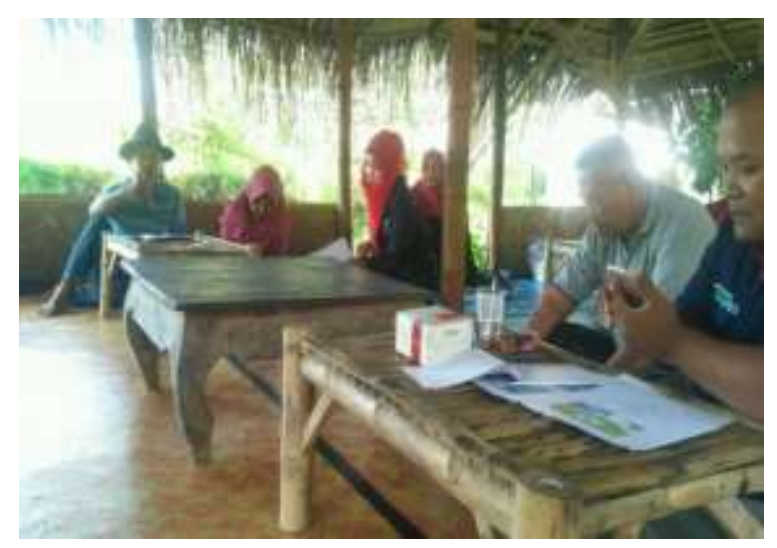

Gambar 8. Penyampaian Materi Manajemen Keuangan dan Pemasaran 


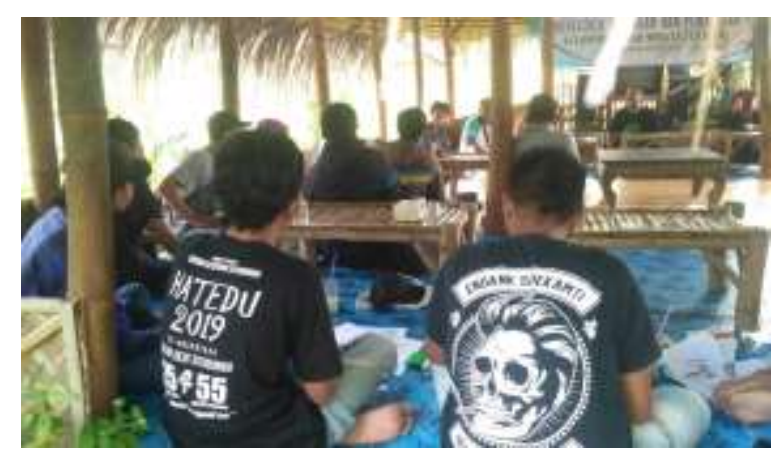

Gambar 9. Pengisian test case

Disini kami menyampaikan mengenai 3 materi yakni materi pengembangan sumber daya manusia (SDM) tentang bagaimana cara mengembangkan SDM yang ada dengan baik, penyampaian materi Keuangan agar masyarakat bisa tau mengenai kas masuk dan kas keluar serta bisa menulis laporan keuangan menggunakan Ms.Word dan Ms.Excel. Disini kami juga menjelaskan tentang materi Manajemen Pemasaran agar mereka mengetahui bagaimana strategi yang tepat untuk mempromosikan pariwisata yang berada di kabupaten Situbondo.

\section{KESIMPULAN DAN SARAN}

\section{Kesimpulan}

Kegiatan PKM pada Kelompok Sadar Wisata di Kabupaten Situbondo yang dilakukan dapat disimpulkan bahwa :

1. Peningkatan pengetahuan dan nilai secara keseluruhan peserta pelatihan mencapai $85 \%$.

2. Hasil evaluasi yang di dapat dari pelatihan di atas adalah peningkatan pengetahuan peserta bisa dibilang baik dalam memahami Manajemen Keuangan dan Manajemen Pemasaran. 


\section{Saran}

1. Potensi-potensi yang ada di Situbondo lebih ditingkatkan lagi oleh seluruh anggota Pokdarwis disetiap daerah.

2. Adanya kesadaran dari masyarakat untuk selalu berperan aktif dalam mencari wawasan pengetahuan tentang pengelolaan keuangan dan pemasaran.

3. Perlunya peran penting Pemerintah Kabupaten Situbondo guna menunjang Sarana dan Prasarana yang dibutuhkan oleh setiap Pokdarwis yang ada di Situbondo.

\section{DAFTAR PUSTAKA}

Arista. D Pemkab Situbondo Canangkan Perekonomian di Tengah Kota. m.rri.co.id/post/berita/425429/ekonomi/pemkab-situbondocanangkan-pusat-perekonomian-ditengah-kota.html. Di akses pada 11 Maret 2019

BPS Kabupaten Situbondo. 2018. Kabupaten Situbondo dalam Angka 2018. Situbondo

Chambers. R. 1996. Memahami Desa Secara Partisipatif. Penerbit Kanisius. Yogyakarta.

Rahim. F. 2012. Pedoman Kelompok Sadar Wisata. Dirjen Kemenpar. Jakarta

Sodiqin. A. Pertumbuhan Ekonomi Situbondo Stagnan. http://www.jawapos.com. Diakses pada 11 Maret 2019

Suryono. A 2014. Kebijakan Publik Untuk Kesejahteraan Rakyat. Jurnal Ilmiah. $\begin{array}{lllll}\text { Vol. } & \text { VI, } & \text { nomer } & \text { Hlm } & 99 .\end{array}$ http://www.google.co.id/url?=t\&source=web\&rct=j\&url. 